\title{
THE DISCOVERY OF THE SUNKEN LOCATION OF KRI NANGGALA-402: THE TRIUMPH OF INDONESIA'S DEFENSE DIPLOMACY?
}

\author{
Putra Hendriman*, Student \\ Moeljadi, Kusumaningrum Adi, Lecturers \\ Postgraduate Program, University of Brawijaya, Malang, Indonesia \\ *E-mail: hendrimanp01@gmail.com
}

\begin{abstract}
Submarines are one of the most important assets in any navy, providing not only strategic advantage, but also create a deterrence effect for potential aggressors. In Indonesia, the submarine squadron and its capability, is designated as a main asset of the Defense Weapon System of Indonesia (ALUTSISTA). In 2021, the Indonesian Navy (TNI-AL) conducted a series of operational testing in the Bali Sea, with submarine KRI Nanggala-402 tasked to conduct a torpedo live firing exercise. However, disaster struck during the preparation phase, and communications were lost with the submarine. An emergency protocol was triggered, with surface vessels and resources were activated to respond to the Search and Rescue (SAR) effort. Due to the time sensitive nature of this event, a diplomatic request was made to friendly countries in the region - countries that Indonesia had close bi-lateral ties - to provide assistance in finding the 56 submarine's crew. The years of strengthening collaboration with Indonesia's neighbors, and its defense diplomacy in the region has paid off. Search and rescue teams from across countries within Asia Pacific region joined hands, in sending surface vessels, rescue ships, and planes in support of this effort. KRI Nanggala-402 was finally found at the bottom of Northern Bali Sea, with hull damages and its entire crew has been lost in this unfortunate incident. While the incident highlighted the risks of submarine forces, it also highlights the growing importance of defense diplomacy in the region. The globalized atmosphere in which we live in, means coalition building, and greater international collaboration are essential to creating a safer region. This research uses applies qualitative analysis, in conjunction with a descriptive analytical approach, to draw lessons from crisis, and study defense diplomacy and its intricacies from an Indonesian's standpoint.
\end{abstract}

\section{KEY WORDS}

Defense diplomacy, Indonesian diplomacy, KRI Nanggala-402.

Indonesia is an archipelagic country that comprises of 17,504 islands and more than $6,400,000 \mathrm{~km}^{2}$ of territorial waters. ${ }^{1}$ In order for the country to be adequately protected, Indonesia's naval force needs to be professional, modern and well equipped. ${ }^{2}$ The Indonesian Navy plays a critical role in defense - protecting territorial integrity, upholding sovereignty, deterring threats and supporting national policy. Based on Republic of Indonesia's Pancasila and the 1945 Constitution, the role of Indonesia's Navy (TNI-AL) is tasked with Military Operations for War (OMP), and Military Operations Other Than War (OMSP). In accordance with Republic of Indonesia (RI) Law No. 34 of 2004 about Tentara Nasional Indonesia (Indonesian Defense Forces/TNI) stated that Indonesian Navy is one of integral part of TNI.

In order to carry out both wartime and peacetime tasks, the Indonesian Navy needs an array of vessels - both surface and underwater - to create a credible deterrence, while playing more peacetime roles in projecting good-will, and to further a country's diplomatic ties and promoting its international agenda.

\footnotetext{
${ }^{1}$ Berita acara rujukan nasional data kewilayahan Republik Indonesia, 2018

${ }^{2}$ https://www.jawapos.com/nasional/21/05/2020/9-program-IASWamana-yudo-usai-dilantik-jadi-ksal. Accessed on May 21,2021.
} 
On the deterrence front, submarines have become one of the most important parts of the Indonesian Navy's Fleet since the establishment of the Fleet Command Submarine Division on September 14, 1959, ${ }^{3}$ which was started by the presence of two Soviet-made Whiskey class submarines. By 1962, the Indonesian Navy had twelve submarines as a tactical strike force at sea. ${ }^{4}$

At that time, Indonesia had became the country with the largest naval power in the Southeast Asia region. As part of the upgrading plan, the Indonesian navy began to replacing the Whiskey-class submarines, with German-made 209/1300 type submarines. $\mathrm{KRI}$ Nanggala was one of the first twelve Whiskey-class submarines build by the Soviet Union which decommissioned on December $12,1966 .^{5}$

In 1977, the Indonesian government ordered two submarines from Germany, and named them KRI Cakra (401) and KRI Nanggala (402). ${ }^{6}$ The two 209/1300 type submarines were designed by Ingenieurkontor in the city of Lubeck, built by Howaldtswerke in Kiel and began construction in March 1978. ${ }^{7}$ The KRI Nanggala-402 was launched on September 10, 1980 and was handed over to the Indonesian Government on July 6, 1981. ${ }^{8}$ and was inaugurated on October 21,1981 at the Madura Pier Surabaya. ${ }^{9}$

The type 209/1300 submarine that is widely used by the world's navies, such as Argentina, Brazil, Chile, Colombia, Ecuador, Egypt, Greece, India, South Korea, Peru, Turkey, South Africa and Venezuela. The submarine was 59.5 meters x 6.2 meters $x$ 5.4 meters in dimensions, had a surface weight of 1,306 tons and a diving weight of 1,412 tons. For the propulsion, it is powered by a diesel electric engine (MTU 12V 493 AZ80 GA31L), four Siemens diesel and one shaft capable of producing 4,600 hp. This results in a surface speed of 11 knots and a dive speed of 21.5 knots. ${ }^{10}$

For the passive \& active systems, the KRI Nanggala-402 is equipped with L-3 ELAC Nautik Lopas 8300 passive sonar, Thomson-CSF Calypso surface radar I-band, ThomsonCSF DR 2000U Electronic Support Measures (ESM), Signaal Sinbad System weapon control system and high-capacity batteries with GRP lead-acid cells from Wilhelm Hagen AG. ${ }^{11}$ With all equipment fitted, the submarine is able to conduct reconnaissance, surface and subsurface warfare.

The ship was originally designed to be manned by a crew of 34 (thirty four) including 6 (six) officers. As part of the strike force, the KRI Nanggala-402 is armed with fourteen 21inch AEG SUT Mod 0 wire-guided active / passive homing torpedoes in eight tubes, with a warhead of $350 \mathrm{~kg}$. These torpedoes are capable of reaching targets at a distance of $12 \mathrm{~km}$ with a speed of 35 knots.

KRI Nanggala-402 carried out several refits/overhauls at the Howaldtswerke Kiel shipyard in Germany between 1986 to 1989, and at Daewoo Shipbuilding and Marine Engineering (DSME) Shipyard in South Korea in 2012. ${ }^{12}$ Based on operating data for the period of 2012-2019, KRI Nanggala-402 has the highest operating hours among other Indonesian Navy submarines, compared to its sister-ship KRI Cakra-401 and the latest generation submarine type DSME 209/1400 (KRI Nagapasa-403, KRI Ardadedali-404 and KRI Alugoro-405.) ${ }^{13}$ The operating data showed that KRI Nanggala-402 reached 590 days of operation while the KRI Cakra-401 recorded 114 days, KRI Nagapasa-403 recorded 123 days and KRI Ardadedali-404 recorded 51 days. ${ }^{14}$

In order to periodically examine the readiness, professionalism and firepower of submarines, the Indonesian Navy conducts a torpedo surface and underwater target

\footnotetext{
${ }^{3}$ Diswatpersal, 2020, Buku Tradisi TNI Angkatan Laut, Publisher Diswatpersal, p.197.

4 lbid, p.200

${ }^{5}$ Ibid, p.201

${ }_{7}^{6}$ Ibid, p.201

${ }^{7}$ lbid

${ }^{8}$ Alex Pape, Jane's Fighting Ships 2019-2020, Surrey: IHS Markit, p.362

${ }^{9} \mathrm{lbid}, \mathrm{p} .202$

${ }_{10} \mathrm{lbid}$

${ }_{12}^{11} \mathrm{lbid}$

12 lbid

${ }_{14}^{13}$ Dongoran, Husain, 'Petaka Lencana Nanggala” (Tempo, 2021) (p.35).

14 Ibid
} 
(SUT) firing exercises. On 21 April 2021, an SUT exercise under the command of Firing Task Force $2^{\text {nd }}$ Fleet Command, involving KRI Nanggala-402 as a firing unit met with tragedy. During the preparation stage, communications were lost with KRI Nanggala-402, and were subsequently declared "submiss" by TNI-AL. ${ }^{15}$

As part of the emergency protocol, ongoing training exercises were stopped, and all units of the Task Force were tasked to Search and Rescue (SAR) immediately. National assets were activated for SAR operations, and in tandem a call for assistance was made to International Submarine Escape and Rescue Liaison Office (ISMERLO) organization, together with international navies operating in the area.

On April 25, $2021 \mathrm{KRI}$ Nanggala-402 was declared "subsunk" at a depth of 838 meters after a sonar detection by KRI Rigel-933 a Hydro-Oceanographic Auxiliary Ship of the TNI$A L$, and visual identification from MV Swift Rescue's Remotely Operated Vehicle (ROV), showing the wreckage, and indicating that all 53 crew have perished in the incident. ${ }^{16}$

The collaborative nature of the incident, across navies highlights the importance of both soft diplomacy and defense diplomacy, in managing crisis.

To further understand the importance of defense diplomacy, the author will use not only the case study of KRI Nanggala-402, but also dissect the article into sections covering legal framework, military defense, and diplomacy theories. The first part discusses Law Number 34 of 2004 concerning the TNI and defense diplomacy theory. The second part briefly describes the chronology of the sinking of the KRI Nanggala-402 and some analyzes of the causes of the sinking of the submarine. The third section looks at the current stance the Indonesian government, and potentially new strategies to mitigate risk. The fourth part discusses the extent where Indonesia's defense diplomacy, played a role in the KRI Nanggala-402 incident.

\section{LITERATURE REVIEW}

Law of the Republic of Indonesia Number 34 of 2004 about TNI. Main task of Indonesian Armed Forces (TNI) is to execute state's defense policies, uphold state sovereignty, maintain territorial integrity, protect national safety, carry out military operations for war, military operations other than war, and actively participate in peacekeeping tasks regionally and internationally.

Based on Republic of Indonesia Law Number 34 of 2004 it defines a national threat, as any effort and activity, both from within the country \& abroad, which threatens or endangers the sovereignty of the state, infringes on territorial integrity, and threatens the safety of the entire nation. Article 5 states that TNI acts as an instrument of the state in the defense sector in carrying out its duties based on state policies and political decisions. Article 6 provides an explanation that TNI's function as a state defense measure, namely: deterring every form of military threat and armed threats, from outside and within the country, that threatens sovereignty, territorial integrity and national safety. TNI is also assigned to take all necessary action against every form of threat, to restoring peace and stability. Furthermore, Article 7 explains the main duties of TNI are as follows:

a) Military Operations for War (OMP);

b) Military Operations Other Than War (OMSP), namely to:

- Overcoming armed separatist movements;

- Overcoming armed rebellion;

- Overcoming acts of terrorism;

- Securing border areas;

- Safeguarding vital installations that are strategic in nature;

- Carry out peacekeeping tasks in accordance with foreign policy policies;

\footnotetext{
${ }^{15}$ https://www.reuters.com/world/asia-pacific/indonesian-navy-checking-submarine-after-failure-report-back-exercise-2021-0421. Accessed on May 21, 2021.

${ }^{16}$ https://nasional.tempo.co/read/1456195/panglima-tni-pastikan-53-kru-kri-nanggala-dipastikan-gugur. Accessed on May 21, 2021.
} 
- Securing the President and Vice President and their families

- Early empowerment of defense areas and supporting forces in accordance with the national defense system;

- Assisting governmental duties in all regions;

- Assisting the National Police of the Republic of Indonesia in the context of security and public order as regulated by law;

- Helping to secure high level state guests and representatives of foreign governments who are currently in Indonesia;

- Assisting in natural disasters, evacuation and providing humanitarian assistance;

- Assisting in search and assistance in accidents / SAR;

- Assisting the government in securing shipping and aviation against piracy, and smuggling.

Furthermore, in specific, the responsibilities of the Indonesian Navy are explained in Article 9, namely carrying out the obligations as part of TNI in the defense sector to assist in enforcing the law and maintaining maritime security national, in accordance with both national and international law, as well as to conduct naval diplomacy. These statutory provisions form the basis elements for the Indonesian Navy to carry out diplomatic roles.

Defense Diplomacy Theory. Defense diplomacy refers to all strategies and approaches, to build trust with related parties. The areas of cooperation encompass culture, politics, defense and diplomacy that are used by a country to build stronger good-will between countries. Defense diplomacy is used as a tool to achieve a country's foreign policy targets. ${ }^{17}$ Gregory Winger in his writing The Theory of Defense Diplomacy explains that defense diplomacy is a way of using the military not for violence, such as officer exchanges, warship visits, joint military exercises in order to achieve a country's international interests. According to Andre Cottey and Anthony Foster, defense diplomacy is the use of the military in peacetime, as a tool for security policy and foreign relations. This is reinforced by Martin Edmons who defines defense diplomacy as the use of the military for operations other than war by leveraging his training and disciplinary experience to achieve national interests both at home and abroad. ${ }^{18}$

The success of the implementation of defense diplomacy is highly dependent on diplomatic efforts at the global, regional and bilateral levels. Of all that, diplomacy at the bilateral level plays a very important role. The success of a country's defense diplomacy strategy is a collaboration of the diplomacy, defense and development components.

Defense diplomacy has 4 (four) motives, such as the strategic engagement, the Confidence Building Measure (CBM), the capacity building, and the international reputation motive. ${ }^{19}$

Strategic engagement aims to increase international interaction and cooperation. Indonesia approaches this, by creating strategic engagement with major countries. Bi-lateral exercise, joint search and rescue exercises and operations are the key, strengthening relations between countries. This platform also offers new opportunities to interact with the military forces of the super-power countries, leading to stronger collaboration and partnerships among international and regional partners.

The Confidence Building Measure (CBM) aims to reduce the risk of aggression, escalating in a conflict situation. This term is most often used in the context of armed conflict, but is logically similar to building trust and interpersonal communication, to reduce conflict situations between individuals.

In international relations, the CBM method is intended to increase trust and reduce suspicion. This involves the exchange of information and allows for verification

\footnotetext{
${ }^{18}$ Rodon Pedrason, Asean's Defense Diplomacy: The Road To Southeast Asian Defense Community. Heidelberg:University Heidelberg, 2015, p. 28

${ }^{18}$ Gregory Winger, The Velvet Gauntlet: A Theory of Defense Diplomacy, IWM Junior Visiting Fellows"s Conferences, vol XXXIII, 2014, p. 4

${ }_{19}$ Frega Inkiriwang, MNEK: Enhancing Indonesia's Multilateral Defense Diplomacy ?, Journal of Current Southeast Asian Affairs 00(0), 22 March 2021,p. 28
} 
of information, particularly information relating to military relations and equipment. With open channels of communication, it enables countries to better analyze and evaluate risk in a more predictable fashion. In defense diplomacy, CBM is used to avoid conflicts or escalating tensions between the two countries. This is in line with the objectives of defense diplomacy in building trust, addressing common security interests, and changing the strategy of relations between countries, as well as reducing feelings of distrust. From a political-military perspective, this interaction helps build the trust that is the basic orientation of a CBM.

The Capacity building aims to improve the abilities of individuals, groups and organizations from knowledge, skills sets, attitudes and behavior. In general, it is a process or activity to improve the ability of a person, group, organization or system to achieve better goals or performance. This is the process of helping individuals or groups to identify problems, gain knowledge and build new experiences needed to solve problems and make dynamic changes.

Various activities carried out include discussions / dialogues between countries, building networks, building cooperation as a team, instruments for regional cooperation and maintaining peace stability. Indonesia's involvement in regional and global activities will be able to identify gaps in order to increase its capabilities.

The international reputation aims to build a positive recognition on the world stage. If the reputation is good, it helps with the country's standing. The reputation of any country encourages or discourages foreign partners from initiating formal relations from the angle of international law, the reputation of another country carries high importance, as country can be fully accepted as a member in international relations, carry out international relations or can carry out cooperative relations with another state. A country with poor reputation does not threaten its survival, but hinders its progression; thus, having a strong standing and good international reputation plays a major role in foreign affairs and policy.

Sequence of Events. On April 21, 2021, the Indonesian Navy conducted a torpedo firing exercise in the Bali Sea, about $95 \mathrm{~km}$ north of Bali Island involving several surface ships, aircrafts and KRI Nanggala-402 as the torpedo firing unit. ${ }^{20}$ At 03.00 WIB the KRI Nanggala-402 requested permission to dive, in preparation for firing the exercise-head torpedo. ${ }^{21}$ At 04.00 WIB KRI Nanggala-402 entered the torpedo tube flooding stage. At 04.25 WIB the last communication between KRI Nanggala-402 and the Task Force Commander who onboard the flagship. At 04.30 WIB, KRI Nanggala-402 lost contact and was declared "sublook" status. At 06.45 WIB, the KRI Nanggala-402 was declared "submiss" status, followed by a large-scale search by units involved in the Strategic Firing Task Force. At $07.00 \mathrm{WIB}$, Navy helicopter found an oil spill in the vicinity of the submarine's lost area, then the Indonesian Navy sent a distress call to the International Submarine Escape and Rescue Liaison Office (ISMERLO) at around 08.37 WIB to report this incident, and requested for assistance in search and rescue.

The Search and Rescue Operation mobilized several national assets consisting of Indonesian warships (Kapal Perang Repubilk Indonesia/KRI) and aircraft, Indonesian government ships such, from the National Marine Police and Basarnas. The assistance also received from international assets consisting of MV Swift Rescue submarine rescue ship from Singapore, MV Mega Bakti submarine rescue ship from Malaysia, SCI Sabarmati submarine rescue ship from India, HMAS Ballarat and the Heli Seahawk S-60 equipped with dipping sonar from Australia, Boeing P-8A Poseidon aircraft from the US Navy and 2 (two) officers from the International Submarine Escape organization and Rescue Liaison Office (ISMERLO).

On April 22, 2021, the Search and Rescue Operation involved 21 surface ships, 1 (one) submarine and 5 (five) aircrafts. The Indonesian Navy stated that one of its units had high potential metal contact using a magnetometer device in the vicinity of the submarine's

\footnotetext{
${ }^{20}$ https://www.janes.com/defense-news/news-detail/update-indonesian-navy-submarine-missing-in-bali-sea. Accessed on May 22, 2021

${ }^{21}$ lbid
} 
lost contact. The Indonesian Navy also stated that the oxygen reserve at KRI Nanggala-402 was sufficient for 53 crews with a duration of 72 hours. On April 23, 2021, the number of units involved were increased by the presence of KRI Rigel-933 which has a multibeam echo sounder capability to detect up to 1000 meters in depths, 4 (four) Marine Police ships as well as HMAS Ballarat and Heli Seahawk S-60 from Australia which are equipped with dipping sonar. On April 24, 2021 Indonesian Navy announced that the KRI Nanggala-402 was declared sunk after the discovery of debris of a torpedo tube straightener, cooling pipe wrapper, periscope lubricant, and some part of room deck. The debris was believed originated from KRI Nanggala-402 which was found about $19 \mathrm{~km}$ from the last point of contact and no other ships were in the area. ${ }^{22}$ On April 25, 2021, an underwater scan carried out by KRI Rigel-933 showed several parts of the submarine, including the rear vertical rudder, anchors, exterior of the press body, and embossed dive rudder. The presence of the MV Swift Rescue from Singapore, equipped with ROV which is capable of diving up to 1000 meters depths and producing underwater imagery, was also able to positively identify the KRI Nanggala-402 wreckage that has been split into three sections. The wreck is located at coordinates $7^{\circ} 48^{\prime} \mathrm{S}-114^{\circ} 51^{\prime} \mathrm{E}$ at a depth of 838 meters, far beyond its maximum operating depth of 500 meters. ${ }^{23}$

Likely Causes of Sinking; Some Analysis. Some of the early analysis, by Wisnu Wardhana, a Submarine expert from the Sepuluh November Institute of Technology (ITS) Surabaya, explaining 3 (three) possible factors causing the incident, such as the malfunction of the Air Ballast which can regulate the dive angle of the ship, malfunctioning hydroplane or wings on the hull and damage The hull was damaged by high water pressure which reached 4 times the hydrostatic pressure from a depth of 200 meters to 800 meters. Wisnu explained that the submarine build by the German Howaldtswerke Kiel industry has approximately 40 years old. In 1980 the submarine was designed to only dive to a depth of 300 meters. However, as the ship gets older, Wisnu predicts that it capable to dive around 200 meters. At a depth that exceeds that threshold, the submarine protective structure, the Pressure Hull, which resembles an eggshell, can cave in due to hydrostatic pressure. According to him, the identification process can be done if the wreck of the KRI Nanggala-402 can be brought ashore. From the debris, more studies can be done to understand what happened to the submarine belonging to the Indonesian Navy. ${ }^{24}$ Defense analyst Connie Rahakundini Bakrie also shared his opinion. Connie received information that the KRI Nanggala-402 had previously experienced rudder problems in March 2021 or about a month before the sinking incident. Rudder system on a submarine are crucial, because if there is damage to the rudder system, the submarine cannot be controlled to dive or return to sea level. ${ }^{25}$ It will make worse if the rudder stuck at an angle of diving, which cause the submarine can continue to dive to crush depth resulting in the destruction of the submarine's hull.

Analysis of the possible reasons of the sinking of the KRI Nanggala was also presented by foreign experts. Submarine observer Peter Coates as Director of Submarine Matters (Australia-US) explained that there were 5 (five) possible causes of the sinking of KRI Nanggala-402. ${ }^{26}$ The first is the human error factor or damage to the torpedo launcher system during the procedure for opening the torpedo launcher door. The procedure for opening the outer bulkhead door and the inner partition door should not be carried out simultaneously. Peter's concern during this procedure, there was a malfunction / human error which resulted in the leak of sea water in a large discharge into the ship, then the submarine lost its buoyancy, such that the forward of the ship tilted forward which led to the submarine falling to the depth of the crush depth. The second cause is a leak in the snorkel system, which causes seawater to enter the ship's battery system and causes

\footnotetext{
${ }^{22}$ https://www.smh.com.au/world/asia/indonesian-submarine-declared-sunk-after-debris-found-20210424-p57m33.html. Accessed on May 24, 2021.

${ }^{23}$ https://news.detik.com/berita/d-5545949/bukti-bukti-otentik-yang-menyatakan-awak-kri-nanggala-402-gugur. Accessed on May 24, 2021.

${ }^{27}$ Https://www.cnnindonesia.com/teknologi/20210427165019-199-635531/ahli-ungkap-3-sebab-kri-nanggala-402-tenggelam850-meter. Accessed on May 28, 2021.

${ }^{25}$ Dongoran, Husain, 'Petaka Lencana Nanggala” (Tempo, 2021) (p.28).

${ }^{26}$ http://gentleseas.blogspot.com/2021/04/. Accessed on May 28, 2021.
} 
an explosion, similar to the sinking incident of the Argentine submarine ARA San Juan in 2017. The third cause is the use of old torpedoes has a high level of risk of occurrence. gas leakage / short circuit in the electrical system that can trigger an explosion in the submarine, such as what happened in the sinking incident of the Russian submarine Kursk in 2000. The fourth cause is that the normal service life of the submarine is in the range of 20 to 25 years, more than that age, average submarine retired. The main reason is that repeated cycles of pressure hull immersion / contraction can lead to material fatigue (metal fatigue). This will of course reduce the dive ability of the submarine compared to the manufacturer's initial technical specifications, with an average maximum dive depth of only 200 meters. If the KRI Nanggala-402 dives at a depth of 250 meters, it is very possible that the pressure hull will not be able to withstand the pressure at that depth and the hull will be compromised.

The Indonesian Navy also provided an analysis of the possible causes of the sinking of KRI Nanggala-402. The Head of the Indonesian Navy Information Service in his press statement stated that there was a possibility that a blackout might occur during static diving, so that the ship was out of control and emergency procedures could not be carried out because there should have been an emergency mechanism to blow so the ship could surface. $^{27}$ The Indonesian Navy also estimates that another cause is weather factors, which is the presence of strong underwater currents known as internal solitary waves. Underwater currents that can create strong vertical drag below sea level occur in the Bali Sea when a submarine makes a dive which then disappears. The United States space agency, NASA stated that the combination of strong tidal currents, uneven seabed and the flow of ocean currents between two channels (one shallow and one deep) tends to occur simultaneously every 14 (fourteen) days and creates tidal flow very strong. These underwater currents are barely visible at sea level, but they can reach massive height. Rear Admiral Muhammad Ali as the Assistant Chief of Indonesian Navy for Planning and Budgeting who is also a former commander of the KRI Nanggala-402 explained that this strong current can drag the submarine vertically so that the ship will sink faster than it should. ${ }^{28}$ The $2^{\text {nd }}$ Fleet Commander, Rear Admiral Iwan Isnurwanto also stated that the Japanese Himawari-8 satellite imagery as well as the European Sentinel satellite, showed a large underwater wave that coincided with the sinking of KRI Nanggala-402. The current moves up from south to north and around it underwater formations. The speed of current is about two nautical miles of sea with a volume of water of about two to four million cubic liters. He asserted that these strong underwater currents were occurring in the waters north of Bali when this Indonesian Navy firing exercise was taking place. ${ }^{29}$

Pro and Cons of Calling for Assistance; a Dilemma. Submarines are not just critical assets due to their stealth, covert, and ability for asymmetric warfare; but it also plays a critical role in deterrence and national policy. Submarine technology, capabilities and limitations are all very sensitive, and such data are kept even from friendly countries and allies. ${ }^{30}$ Thus the decision to request for foreign assistance to aid with the recovery of KRI Nanggala-402 will also expose vulnerability of the secretive platform. Between maintaining secrecy, and saving lives, the TNI-AL made the difficult decision to request for assistance, as there was 72 hours oxygen left onboard the ship, and any hope of finding survivors relied on getting as much help as possible.

There are consequences when Indonesia decided request for support from other countries. First, the presence of military operations/training, secrecy of submarine technology will be exposed. Should a failed attempt at rescuing the crew, there will be not only domestic but also international repercussions.

\footnotetext{
${ }^{27} \mathrm{Https}$ ///nasional.sindonews.com/read/404794/14/sebelum-hilang-kontak-kri-nanggala-402-diduga-alami-blackout1619053485. Accessed on May 28, 2021.

${ }^{28}$ https://www.rnz.co.nz/news/world/441531/indonesia-submarine-sinking-internal-wave-likely-to-blame-experts. Accessed on June 02, 2021.

${ }^{32}$ Https://www.jpnn.com/news/seperti-apa-arus-bawah-laut-yang-disebut-sebut-penyebab-tenggelamnya-kri-nanggala-402. Accessed on May 29, 2021.

${ }^{30}$ Dickry Rizanny, 2020, Recalling Indonesia's Maritime Path, Publisher Nas Media Pustaka, p.228.
} 
From the foreign policy front, such requests as requesting for assistance may suggest an array of a lacks in the TNI-AL, from a lack of capability, to professionalism, to effectiveness in underwater detection, maintenance procedures, the negligence of logistics crews, and to the use of obsolete equipment. While the Indonesian Navy has assets with underwater detection capabilities, it still lacks deep sea visual detection capability in the form of ROVs. Should the Indonesian Navy continue to ask for help from friendly countries, it inevitability raises doubts professionalism of the crew in optimizing the use of the currently existing underwater detection-capable defense equipment.

The location of the sinking of the KRI Nanggala-402 as stated on the nautical map of the Indonesian Navy Hydro Oceanographic Center is a designated area for training of surface, subsurface and air assets of the Indonesian Navy. The disappearance of the submarine is inside the training area of Indonesian Navy, also means giving foreign navies access to these potentially sensitive areas; and raise concerns about a lack of familiarity of naval crews operating in their own territorial waters.

Third, Submarines as one of the components of the Indonesian Navy's strength are characterized by their ability to operate below sea level with a high level of risk. The risk of emergencies can be caused by weather, technical equipment as well as the crew onboard. An emergency for a submarine crew is often life threatening, due to the pressurized environment. Thus, submarine emergencies require prompt, precise, systematic, and well-coordinated response. Some emergency procedures that can be carried out by submarines include firing red pyrotechnic signals or floating flares on the surface of the water, sending radio distress signals from the Emergency Position Indicator Radio Beacon (EPIRB), sending emergency signal via Under Water Telephone (UWT) and sending emergency signals acoustic sonar beacon. ${ }^{31}$ All TNI-AL submarine crew have been trained to adhere to emergency procedures. In the case of the sinking of $\mathrm{KRI}$ Nanggala-402, there was no distress signal of any kind, indicating that a catastrophic incident has occurred, and prevented the crew from executing these emergency procedures in time.

Fourth, it is also suggested that KRI Nanggala-402 was sea-worthy, however this has been clarified by the TNI-AL that the a recent inspection of the ship's worthiness was made just days before the submarine left for sailing. ${ }^{32} \mathrm{KRI}$ Nanggala-402 also routinely undergoes periodic maintenance every 2 (two) years at PT PAL Indonesia. ${ }^{33}$ The last periodic maintenance was last carried out in December 2019 to January 2020 and KRI Nanggala-402 was declared operational worthy until September 8, 2022. ${ }^{34}$

It is however possible, that due to age, the material strength has gradually deteriorated. KRI Nanggala-402 along with its sister ship, KRI Cakra-401 has been in service in the Indonesian Navy since July 1981 and at the point of incident, these vessels are 40 years old. According to the experts the submarine was designed to dive to a maximum depth of $300 \mathrm{~m}$. However, as the ship gets older, a maximum operating depth of $200 \mathrm{~m}$ is more realistic. ${ }^{35}$ This is due to wear and tear from repeated cycles of pressurization, causing the entire hull to flex, resulting in structural fatigue. ${ }^{36}$

In other hands, there are also consequences must be faced by Indonesian Navy if it refuses to request for international assistance. First, as we know, Indonesian Navy has several surface and air assets equipped with underwater detection sensors for the implementation of anti-submarine warfare (ASW), including KRI RE Martadinata class, KRI Diponegoro class, KRI Bung Tomo class, KRI Pattimura class, KRI Cakra class submarine, KRI Nagapasa Class Submarine and AS 565 Mbe ASW Panther Helicopter. ${ }^{37}$ The Indonesian Navy also has several underwater detection equipment for

\footnotetext{
${ }^{31}$ http://www.hydro.gov.au/information-concerning-submarines-warning-signals. Accessed on May 24, 2021.

${ }^{32}$ Dongoran, Husain, "Petaka Lencana Nanggala" (Tempo, 2021).

${ }_{33}$ Ibid.

${ }^{34} \mathrm{lbid}$.

${ }^{35}$ https://news.detik.com/berita/d-5545949/bukti-bukti-otentik-yang-menyatakan-awak-kri-nanggala-402-gugur.Accessed on May 25, 2021.

${ }^{36} \mathrm{http}: / /$ gentleseas.blogspot.com/2021/04/. Accessed on June 02, 2021.

${ }^{37}$ Alex Pape, Jane's Fighting Ships 2019-2020, Surrey: IHS Markit, p.361
} 
the implementation of ASW such as Hull Mounted Sonar, Dipping Sonar, Magnetic Anomaly Detector, Forward Looking Infra-Red (FLIR) and Underwater Telephone as well as underwater detection equipment for conducting hydro oceanographic survey operations ranging from Multibeam Echo Sounder, Side Scan Sonar, Magnetometer, Underwater Positioning (USBL) Transceiver, Acoustic Doppler Current Profiler (ADCP), and Remotely Operated Vehicle (ROV). ${ }^{38}$ However, the Indonesian Navy still needs to improve its capabilities with high-tech underwater detection equipment such as the Unmanned Underwater Vehicle (UUV) which can reach a depth of up to 1000 meters for visual detection. The Indonesian Navy also does not have yet a Submarine Rescue Vessel (SRV) which has the ability to rescue submarine crew in an emergency. Therefore, it is prudent for the TNI-AL to request for international assistance.

Secondly, the humanitarian aspect is one of the most importance considerations. The lives of all 53 crew members of KRI Nanggala- 402 were at stake, and savings lives took precedence during the incident, any surviving crew had less than 3 (three) of life support. Should the decision be delayed, any chances of finding survivors will be zero.

In view of this, the Chief of Staff of Indonesian Navy advised Indonesian Armed Forces (TNI) Commander to request assistance from friendly countries to conduct search and rescue operations. ${ }^{39}$ This appeal was made just a few hours after the KRI Nanggala-402 lost contact. Indonesian Navy sent a call for assistance to the International Submarine Escape and Rescue Liaison Office (ISMERLO) to report the status of the missing submarine.

For Indonesia its self, the calling for assistance is not simply about rescuing KRI Nanggala-402, even though this is the most important, but also can be seen as to what extent Indonesian's defense diplomacy working on this situation. It can be argued that if the calling is responded by other countries, then it might be seen as a positive achieving of Indonesian defense diplomacy. Otherwise, less respond can be assumed as the failure of Indonesian's defense diplomacy to play its role. Therefore, next session will examine how Indonesian's defense diplomacy working on search and rescue operations of KRI Nanggala402.

The Implementation of Indonesian Defense Diplomacy; the Concrete Proof. Diplomacy and defense are two inseparable entities as both aims to ensure peace and safety, through cooperation, transparency, and trust building between nations and militaries. Diplomacy in the traditional sense, refers to efforts carried out between countries in realizing peace, achieving state strategic interests or national interests (national interest), economic and trade interests. Thus, defense diplomacy is a combination of various disciplines, with cross sectoral partnerships between civilian and military organization, all working in tandem in support for international relations. The concept of defense diplomacy is a combination of national policies implemented in the defense sector. The ideal condition is to combine the military and development components. ${ }^{40}$ In peacetime, the use of the military in state diplomacy aims for deterrence and building goodwill. Many countries have exemplified how the military can possibly rejuvenate itself to address defense and security issues without the use of force. Examples of such efforts are also shown by China when it tried to win a tender for the construction of airports and roads in Tanzania. China uses its military as a diplomatic tool by providing military assistance to the Tanzanian military and contributing to the construction of thousands of homes for Tanzanian soldiers. This method succeeded in winning over the Tanzanian government and the tender was won by China. ${ }^{41}$

One of President Joko Widodo manifesto in 2014 was to expand regional diplomacy to the Indo-Pacific region. ${ }^{42}$ Until now, several cooperative relationships that have been carried out as diplomatic implementations include:

\footnotetext{
${ }_{38}^{38}$ Dispenal, 'Mengenal Lebih Dekat KRI Rigel-933" (Cakrawala, Edition 426, 2015) (p.29).

39 https://www.cnnindonesia.com/nasional/20210421195138-20-633057/tni-minta-bantuan-singapura-australia-cari-krinanggala-402. Accessed on May 22, 2021.

${ }_{40}$ Safril Hidayat, Diplomasi Pertahanan Indonesia:Amalgam Militer Sipil, Jurnal Pertahanan, vol 4, No. 2, Agustus 2014, hal. 28

${ }^{41}$ Budyanto Sudarsono, Diplomasi Pertahanan Indonesia Dalam Mencapai Kepentingan Nasional, Jurnal Pertahanan dan Bela Negara, vol 8, No. 3, Desember 2018, hal. 85

${ }^{42}$ Dickry Rizanny, 2020, Recalling Indonesia's Maritime Path, Publisher Nas Media Pustaka, hal.16
} 
1) ASEAN. The Association of Southeast Asian Nations (ASEAN) was founded on August 8, 1967 in Bangkok by five founding countries, Indonesia, Malaysia, the Philippines, Singapore and Thailand. ${ }^{43}$ On January 8, 1984 Brunei Darussalam officially became a member of ASEAN. On 28 July 1995 Vietnam joined ASEAN and on 23 July 1997 followed by Laos and Myanmar. Cambodia became the last member of ASEAN on April 30, 1999. Currently, ASEAN has ten members in Southeast Asia.

2) Bilateral. Currently, Indonesia has established bilateral cooperation with 162 countries as well as one special territory in the form of a non-self-governing territory. ${ }^{44}$ These bi-lateral relationships are divided into eight regions, consisting of Africa, Middle East, East Asia, Pacific, South Asia and Central Asia. Then in America, including North America, Central America, South America and the Caribbean, as well as the areas in the European Continent including Western Europe, Central Europe and Eastern Europe.

3) Multilateral. Indonesia's commitment to the implementation and formulation of international rules and law, maintaining the importance of the principles of multilateralism in international relations, and opposing unilateralism, aggression and the use of all forms of violence in solving international problems, among others, through the OIC, ANRPC, Colombo Plan, D-8, G-15, NAM, G-77 and China, South - South Cooperation, South Center and WTO (Tourism). In multilateral diplomacy, Indonesia has also actively participated in efforts to uphold world security and order by being involved in UN peacekeeping operations. On May 1, 2019, Indonesia was also officially elected as the head of the UN Security Council.

TNI participates in carrying out diplomacy in accordance with the country's political policies through various activities including maintaining peace and realizing security. TNI has been a regular participant in UN peacekeeping missions. In the ASEAN scope, TNI also plays an active role in building communication with the militaries of friendly countries through meeting forums such as the ASEAN Defense Ministerial Meeting which aims to build a common interest and consensus among the armed forces of ASEAN countries and their partners regarding regional security, enhance mutual trust and identify new areas for cooperation. Indonesia is also the organizer of the Jakarta International Defense Dialogue (JIDD) meeting, which is an international forum that discusses global security issues.

The Indonesian Navy as an integral part of TNI carries out the roles and functions of TNI, however, beyond the traditional role of defense, it also plays a broader role in building diplomacy. Diplomacy is a very important role for every Navy around the world as it supports government foreign policy and is designed to influence the leadership of a country or several countries in peaceful conditions or in hostile situations. The Indonesian Navy has various bilateral and multilateral collaborations with navies in the Southeast Asian and global regions, including Australia, Malaysia, Singapore, Thailand, Philippines, Brunei Darussalam, Vietnam, India, Pakistan, China, Japan, South Korea, Britain, Netherlands and United States of America. This international cooperation is a form of defense diplomacy by the Indonesian Navy in the context of building Confidence Building Measures (CBM) and achieving harmonization among related countries. ${ }^{45}$

Maritime diplomacy is a form of defense diplomacy by the Indonesian Navy in the context of Confidence Building Measures (CBM). Therefore, maritime diplomacy activities carried out with goodwill, coordinated patrols, peace assignments, and joint exercises which are expected to foster mutual trust between countries. The array of activities carried out with maritime diplomacy in mind - have been able to reduce the intensity of violations in the seas of Indonesia's national jurisdiction such as illegal fishing, violations of sovereignty, territorial disputes, piracy and pollution. Maritime diplomacy carried out by the Indonesian Navy, in the form of deploying a KRI to a country, to support an Indonesian delegation, or to participate in negotiations, that builds mutually beneficial

\footnotetext{
${ }^{43}$ https://www.asean.org/asean/about-asean/history. Accessed on May 22, 2021.

44 https://www.kemlu.go.id/download/. Accessed on May 22, 2021.

${ }^{45}$ Dickry Rizanny, 2020, Recalling Indonesia's Maritime Path, Publisher Nas Media Pustaka, hal.170.
} 
cooperation between countries; the presence of $\mathrm{KRI}$ in these roles achieving the goals of maritime diplomacy. ${ }^{46}$

Several forms of maritime diplomacy efforts have been implemented along with the countries in the region include:

1) Bilateral diplomacy in the form of coordinating patrols with India, the Philippines, Singapore, Malaysia, Australia. ${ }^{47}$ The bilateral "Indindo" joint exercise between IndonesiaIndia, the Indonesia-Singapore "Eagle Indopura" exercise, the Indonesia-Malaysia "Malindo Jaya" exercise, the Indonesia-Brunei "Sea-Helang" exercise, the Indonesia-Thailand "Seagaruda" exercise, the " The Indonesia-Australia New Horizon, the "black coral" exercise between Indonesia-Pakistan and the Indonesia-United States "Carat" exercise. Navy to Navy Talk with Singapore, Vietnam, Thailand, India, Pakistan, Australia, China, Japan, Netherlands, UK and United States. ${ }^{48}$

2) Multilateral diplomacy in the form of multinational joint exercise "Multilateral Naval Exercise Komodo" held by Indonesia ${ }^{49}$, sending representatives to the "International Maritime Defense Expo" organized by Singapore ${ }^{50}$, "Kakadu Exercise" held by Australia ${ }^{51}$, "AMAN Exercise" held by Pakistan ${ }^{52}$, " Pacific Reach "organized by South Korea," "Sea Cat Exercise and Rim of Pacific Exercise" organized by the United States of America and "International Fleet Review "conducted by Thailand, Australia, New Zealand and China. ${ }^{53}$

The defense diplomacy that has been carried out by Indonesian Navy through various activities has fulfilled the four-defense diplomacy objectives, which are the strategic engagement, the Confidence Building Measure (CBM), the capacity building, and the international reputation building. However, achieving of the defense diplomacy's goals, which was implemented by Indonesian Navy, then has been challenged by the incident of KRI Nanggala-402.

When the first communications lost, TNI Commander immediately asked friendly countries to join the search and rescue mission for KRI Nanggala-402 in Bali waters. This request for assistance was quickly responded by friendly countries, both from Southeast Asian countries and globally, including Singapore, Malaysia, Australia, India, Turkey, France, Germany, Russia and the United States of America. ${ }^{54}$ Supporting from the International Submarine Escape and Rescue Liaison Office (ISMERLO) also available while two ISMERLO officers assisting the search and rescue mission.

Various aid assets are offered by friendly countries in the form of warships capable of underwater detection, submarine rescue ships, tankers, helicopters with underwater detection capabilities, aircraft capable of underwater detection, Remotely Operated Vehicle (ROV), Deep Submergence Rescue Vehicle (DRSV), Compression chamber, side scan sonar, medical personnel specializing in decompression and experts in the field of submarine rescue. Assets assistance from the closest friendly countries in the region is a top priority in this search and rescue mission because it is a race against the time related to the oxygen reserve of KRI Nanggala- 402 which is only enough for 72 hours since the submarine was declared missing.

Singapore is one of the countries with the quickest responds by dispatching a submarine rescue ship, MV Swift Rescue departed to the search and rescue area 5 (five) hours after receiving a request for assistance from Indonesia. MV Swift Rescue supported the search effort with its Remotely Operated Vehicle (ROV), Deep Submergence Rescue Vehicle (DRSV), compression chamber and medical personnel specializing

\footnotetext{
46 Ibid, hal. 131

47 Ibid, hal. 30

${ }^{48}$ https://www.fkpmar.org/navy-to-navy-talk-sebagai-sarana-untuk-menjalin-kerjasama-maritim/. Accessed on May $22,2021$.

${ }^{49}$ Dickry Rizanny, 2020, Recalling Indonesia's Maritime Path, Publisher Nas Media Pustaka, hal.30.

50 https://www.tni.mil.id/view-112567-kapal-perang-tni-al-jajaran-koarmatim-ikuti-internasional-maritime-defense.html. Accessed on May 27, 2021.

${ }^{51}$ https://koarmada2.tnial.mil.id/2018/09/01/latihan-bersama-kakadu-2018-resmi-dibuka/. Accessed on June 1, 2021.

${ }^{52}$ https://koarmada1.tnial.mil.id/artikel/detail/216-tni-al-ikuti-multinational-exercise-aman-21-di-pakistan. Accessed on June 3, 2021.

${ }^{53}$ https://koarmada2.tnial.mil.id/2017/11/23/event-asean-ifr-2017-resmi-di-tutup/. Accessed on June 3, 2021.

${ }^{54}$ https://www.voaindonesia.com/a/negara-termasuk-as-tawarkan-bantuan-cari-kapal-selam-ri/5862662. html. Accessed on June 2, 2021.
} 
in decompression. Malaysia responded by sending a submarine rescue ship, the MV Mega Bakti, equipped with ROV, compression chamber and medical personnel specializing in decompression. India responded by sending a submarine rescue ship, SCI Sabarmati, equipped with an ROV and DSRV. Australia responded by sending a warship capable of underwater detection, HMAS Ballarat and helicopters capable of underwater detection Seahawk S-60 and the United States responded by sending a Boeing 737 P-8 Poseidon aircraft $^{55}$ that has underwater detection capability using active-passive sonobuoy. Countries outside the ASEAN region, such as Turkey, France, Germany, and Russia, said they were ready to send experts in the submarine area at any time when Indonesia needed it. The ISMERLO organization also assisted by coordinating international submarine community to provide assistance as soon as possible. It was followed up by sending officers who expert in submarine rescue to support Indonesian Navy in this incident. ${ }^{56}$

Defense diplomacy carried out by Indonesia provides opportunities for interaction at the strategic and operational levels with other countries including super power countries such as the United States of America which also deployed their assets during the SAR effort. Defense diplomacy has also built a confidence building measure so that the international community responds quickly to mutual calls for assistance, working together for better good, and reducing distrust. Capacity building has also been achieved, which can be seen from the interoperability involved in the search mission. Different countries, with an array of assets, all working together on tasks assigned by the SAR Mission Commander. Communication and coordination between surface and air assets is well established through LO exchange, as well as shared communication protocols, and procedures used (Result of an interview with one of the Indonesian Navy Officers involved in a search mission, 2021). International reputation of each country is implemented by providing the necessary assets and optimal performance during the search and rescue mission. The search and rescue operation ultimately ended when the last position of KRI Nanggala-402 was located (by KRI Rigel) and underwater images of the debris of KRI Nanggala-402 were provided (by MV Swift Rescue).

Without regardless the humanitarian aspect, it can be stated that the finding of location of KRI Nanggala-402 is a proven of the successful of defense diplomacy carried out by Indonesia, through Indonesian Navy. In other words, Indonesian's defense diplomacy has succeeded playing its role during search and rescue mission of KRI Nanggala-402. It can be seen from the overwhelming international response when Indonesia decided to ask friendly countries for assistance in search and rescue operation of KRI Nanggala-402. The collaboration among the assets from different countries in the area of SAR has given an instance in this case. In this context, the collaboration is highly likely failed without mutual trust among the countries. The way to build mutual trust had been done by Indonesian Navy through strategic engagement, Confidence Building Measure (CBM), the capacity building, and the international reputation building either bilaterally or multilaterally. Four motives of the defense diplomacy have become foundations for Indonesia, especially for Indonesian Navy, in tightening the relation with other countries.

\section{CONCLUSION}

The Indonesian Navy continues to carry out defense diplomacy roles as mandated by the constitution. With the four motives embedded within defense diplomacy, which are the strategic engagement, the Confidence Building Measure (CBM), the capacity building, and the international reputation; all these have been witnessed through this incident. This research shows that that defense diplomacy carried out by Indonesian Navy, not only served as a deterrent, but also creates opportunities for regional corporation to address issues that cannot resolved by a country on its own. The speed at which requests for

\footnotetext{
${ }^{55}$ https://www.voaindonesia.com/a/sejumlah-kapal-asing-bantu-cari-kri-nanggala-402-sebelum-oksigen-habis/5864442.html. Accessed on June 5, 2021.

${ }^{56}$ https://www.cnnindonesia.com/internasional/20210423104001-134-633786/mengenal-ismerlo-organisasi-tanggappenyelamatan-kapal-selam. Accessed on June 6, 2021.
} 
assistance, and help arrived - can be seen as a result Indonesia's defense diplomacy which is carried out both bilaterally and multilaterally through the years.

Based on the conclusion, the researcher recommends the need for the Indonesian government to formulate an overarching strategy for strengthening its defense diplomacy, both bilaterally and multilaterally. The Indonesian government also needs to increase the capabilities of the Navy with a Submarine Rescue Vessel so that it can carry out submarine' SAR operations. This capability provides assurance not just for TNI-AL's submarine crew, but can also serve as a first responder to support other countries that may need assistance. This again, enhances its defense diplomacy. Moreover, further research is needed to determine the appropriate model for the development of the Indonesian Navy's capacity in order to support an overarching strategy of Indonesian's defense diplomacy.

\section{REFERENCES}

1. Alex Pape, Jane's Fighting Ships 2019-2020, Surrey: IHS Markit, 2019.

2. Dickry Rizanny, Recalling Indonesia's Maritime Path, Penerbit Nas Media Pustaka, 2020.

3. Diswatpersal, Buku Tradisi TNI Angkatan Laut, Penerbit Diswatpersal, 2020.

4. Gregory Winger, "The Velvet Gauntlet: A Theory of Defense Diplomacy", IWM Junior Visiting Fellows"s Conferences, vol XXXIII, 2014.

5. Safril Hidayat, "Diplomasi Pertahanan Indonesia: Amalgam Militer Sipil", Jurnal Pertahanan, vol 4, No. 2, 2014.

6. Rodon Pedrason, “Asean's Defense Diplomacy: The Road to Southeast Asian Defense Community". Heidelberg:University Heidelberg, 2015.

7. Budyanto Sudarsono, "Diplomasi Pertahanan Indonesia Dalam Mencapai Kepentingan Nasional", Jurnal Pertahanan dan Bela Negara, vol 8, No. 3, 2018.

8. Frega Inkiriwang, "MNEK: Enhancing Indonesia's Multilateral Defense Diplomacy?" Journal of Current Southeast Asian Affairs 00(0), 2021.

9. https://www.jawapos.com/nasional/21/05/2020/9-program-IASWamana-yudo-usaidilantik-jadi-ksal. Accessed on May 21,2021.

10. https://www.reuters.com/world/asia-pacific/indonesian-navy-checking-submarine-afterfailure-report-back-exercise-2021-04-21. Accessed on May 21, 2021.

11. Https://nasional.tempo.co/read/1456195/panglima-tni-pastikan-53-kru-kri-nanggaladipastikan-gugur. Accessed on May 21, 2021.

12. https://www.janes.com/defense-news/news-detail/update-indonesian-navy-submarinemissing-in-bali-sea. Accessed on May 22, 2021.

13. https://www.smh.com.au/world/asia/indonesian-submarine-declared-sunk-after-debrisfound-20210424-p57m33.html. Accessed on May 24, 2021.

14. https://news.detik.com/berita/d-5545949/bukti-bukti-otentik-yang-menyatakan-awak-krinanggala-402-gugur. Accessed on May 24, 2021.

15. https://www.cnnindonesia.com/teknologi/20210427165019-199-635531/ahli-ungkap-3sebab-kri-nanggala-402-tenggelam-850-meter. Accessed on May 28, 2021.

16. http://gentleseas.blogspot.com/2021/04/. Accessed on May 28, 2021.

17. https://nasional.sindonews.com/read/404794/14/sebelum-hilang-kontak-kri-nanggala402-diduga-alami-blackout-1619053485. Accessed on May 28, 2021.

18. https://www.rnz.co.nz/news/world/441531/indonesia-submarine-sinking-internal-wavelikely-to-blame-experts. Accessed on June 02, 2021.

19. https://www.jpnn.com/news/seperti-apa-arus-bawah-laut-yang-disebut-sebut-penyebabtenggelamnya-kri-nanggala-402. Accessed on May 29, 2021.

20. http://www.hydro.gov.au/information-concerning-submarines-warning-signals. Accessed on May 24, 2021.

21. https://news.detik.com/berita/d-5545949/bukti-bukti-otentik-yang-menyatakan-awak-krinanggala-402-gugur.Accessed on May 25, 2021.

22. http://gentleseas.blogspot.com/2021/04/. Accessed on June 02, 2021. 
23. https://www.cnnindonesia.com/nasional/20210421195138-20-633057/tni-minta-bantuansingapura-australia-cari-kri-nanggala-402. Accessed on May 22, 2021.

24. https://www.asean.org/asean/about-asean/history. Accessed on May 22, 2021.

25. https://www.kemlu.go.id/download/. Accessed on May 22, 2021.

26. https://www.fkpmar.org/navy-to-navy-talk-sebagai-sarana-untuk-menjalin-kerjasamamaritim/. Accessed on May 22, 2021.

27. https://www.tni.mil.id/view-112567-kapal-perang-tni-al-jajaran-koarmatim-ikutiinternasional-maritime-defense.html. Accessed on May 27, 2021

28. https://koarmada2.tnial.mil.id/2018/09/01/latihan-bersama-kakadu-2018-resmi-dibuka/. Accessed on June 1, 2021.

29. https://koarmada1.tnial.mil.id/artikel/detail/216-tni-al-ikuti-multinational-exercise-aman21-di-pakistan. Accessed on June 3, 2021.

30. https://koarmada2.tnial.mil.id/2017/11/23/event-asean-ifr-2017-resmi-di-tutup/. Accessed on June 3, 2021.

31. https://www.voaindonesia.com/a/negara-termasuk-as-tawarkan-bantuan-cari-kapalselam-ri/5862662.html. Accessed on June 2, 2021.

32. https://www.voaindonesia.com/a/sejumlah-kapal-asing-bantu-cari-kri-nanggala-402sebelum-oksigen-habis/5864442.html. Accessed on June 5, 2021.

33. https://www.cnnindonesia.com/internasional/20210423104001-134-633786/mengenalismerlo-organisasi-tanggap-penyelamatan-kapal-selam. Accessed on June 6, 2021.

34. Undang-Undang Republik Indonesia Nomor 34 Tahun 2004 tentang Tentara Nasional Indonesia.

35. Dispenal, 'Mengenal Lebih Dekat KRI Rigel-933” (Cakrawala, Edition 426, 2015).

36. Pushidrosal, 'Rujukan Nasional Data Kewilayahan Republik Indonesia' (2018), Jakarta. 